\title{
Maps showing distribution of dissolved solids and dominant chemical type in ground water, Basin and Range province, Nevada
}

by

Thomas H. Thompson and Richard Chappell

\section{Introduction}

This map report is one of a series of geologic and hydrologic maps of states in the Basin and Range Province. These map reports contain information on ground-water hydrology, ground-water quality, surface distribution of selected rock types, data on tectonic conditions, areal geophysical data, Pleistocene lakes and marshes and natural resources. This information is the basis for a summary report that characterizes the Basin and Range province. The geologic and hydrologic characterization will be used to evaluate the Province for prospective regions for further study relative to isolation of high-level radioactive waste. (Bedinger, Sargent and Reed, 1984). 
Chemical quality of ground water

Ground-water quality in the Basin and Range Province of Nevada was charcterized by dissolved-solids concentration and dominant anions and cations in solution. Water-quality information was compiled from the U.S. Geological survey waterquality files (WATSTORE), published reports of the U.S. Geological Survey, and various State agencies of Nevada.

The data on dissolved-solids concentration and water-quality type were plotted and their distributions mapped in the basin-fill deposits from the data compiled for samples collected from nongeothermal springs and wells of less than 501 feet in depth. In areas for which data were not compiled, other data sources and published reports were consulted where available. In lieu of data, the parameters in the basin-fill were estimated from the position in the ground-water flow system and the lithology of the adjacent bedrock. Data from wells greater than 500 feet in depth are included as supplemental data, but are not used in mapping dissolved-solids concentration or water-quality type. Data from wells greater than 500 feet in depth are not reflected in the mapped areas where the data are not believed to be representative of a significantly large area. 
Distribution of dissolved solids

Dissolved-solids concentration of major anions and cations was calculated from analyses using the following equation: Dissolved solids $=$

$$
\mathrm{Ca}+\mathrm{Ma}+\mathrm{Na}+(0.4917)\left(\mathrm{HCO}_{3}\right)+\mathrm{SO}_{4}+\mathrm{Cl}+\mathrm{K}+\mathrm{Sr},
$$

where the concentration of each component, calcium, $\mathrm{Ca}$; magnesium, Mg; sodium, Na; bicarbonate, HCO ; sulfate, so ; chloride, $\mathrm{Cl}$; potassium, $\mathrm{K}$; and strontium, $\mathrm{Sr}$; is in milligrams per liter $(\mathrm{mg} / \mathrm{L})$.

\section{Water-quality type}

The dissolved-solids composition of a water consists primarily of six major ions: the three cations - calcium, magnesium, and sodium; and the three anions - bicarbonate, sulfate, and chloride. Relative proportions of these cations and anions can be displayed on trilinear diagrams: Waters of similar ionic proportions, and thus of similar chemical character, plot near one another. Therefore, areas of chemically similar waters can be delineated on the trilinear diagrams. For the purposes of this study, each trilinear diagram is divided into seven areas as shown in the accompanying illustration.

water quality in basin fill is characterized by dominant cations and anions in solution and is shown in the accompanying map. The explanation lists dominant cation(s) and anion(s) combinations mapped in each area. 


\section{Selected Befereneces}

Bateman, R. L., and Hess, J. W., 1978, Hydrologic inventory and evaluation of Nevada playas: Las Vegas, Nevada, University of Nevada System, Desert Research Institute, Water Resources Center Project Report no. 49, 22 p.

Bateman, R. L., and Scheibach, R. B., 1975, Evaluation of geothermal activity in the Truckee Meadows, Washoe County, Nevada: Nevada Bureau of Mines and Geology Report 25, 38 p. Bedinger, M. S., Sargent, K. A., and Reed, J. E., 1984, Geologic and hydrologic characterization and evaluation of the Basin and Range Province relative to the disposal of high-level radioactive waste--Part $I$, Introduction and guidelines: U.S. Geological Survey Circular 904-A, 67 p., [in press]. Blankennagel, R. K., and Weir, J. E., Jr., 1973, Geohydrology of the eastern part of Pahute Mesa, Nevada Test Site, Nye County, Nevada: U.S. Geological Survey Professional Paper $83-712-B, 35$ p.

Carpenter, Everette, 1915, Groundwater in southeastern Nevada: U.S. Geological Survey, Water-Supply Paper 365, 86 p. Cohen, Philip, 1964, A brief appraisal of the ground-water resources of the Grass Valley area, Humboldt and Pershing Counties, Nevada: Nevada Department of Conservation and Natural Resources Ground-water Resources Reconnaissance Series Report 29, 40 p.

---- 1965, Water resources of the Humboldt River Valley near Winnemucca, Nevada: U.S. Geological Survey Water Supply Paper $1795,143 \mathrm{p}$. 
---- 1966, Water in the Humboldt River Valley near Winnemucca, Nevada: U.S. Geological Survey Water-Supply Paper 1816, 69 p. Cohen, Philip, and Loeltz, O. J., 1964, Evaluation of hydrogeology and hydrogeochemistry of Truckee Meadows area, Washoe County, Nevada: U.S. Geological Survey Water-Supply Paper 1779-S, 63 p.

Crosthwaite, E. G., 1963, Ground-water appraisal of Antelope and Middle Reese River Valleys, Lander County, Nevada: Nevada Department of Conservation and Natural Resources Ground-water Resources Reconnaissance Series Report 19, 33 p.

Davis, J. R., and Vine, J. D., 1979, Stratigraphic and tectonic setting of the lithium brine field, Clayton Valley, Nevada, in Newman, G. W., and Goode, H. D., eds., 1979 Basin and Range Symposium and Great Basin Field Conference: Denver, Colorado, Rocky Mountain Association of Geologists, p. 421-430.

Dudley, W. W., Jr., and Larson, J. D., 1976, Effect of irrigation pumping on desert pupfish habitats in Ash Meadows, Nye County, Nevada: U.S. Geological Survey Professional Paper 927,52 p.

Eakin, T. E., Hughes, J. L., and Moore, D. O., 1967, Waterresources appraisal of Steptoe Valley, White Pine and Elko Counties, Nevada: Nevada Department of Conservation and Natural Resources Water Resources Reconnaissance Series Report 42,48 p. 
Eakin, T. E., Maxey, G. B., and Robinson, T. W., 1951, [1949], Ground water in Goshute - Antelope Valley, Elko County, Nevada, in Eakin, T. E., Maxey, G. B., Robinson, T. W., Fredericks, J. C., and Loeltz, O. J., eds., Contributions to the hydrology of eastern Nevada, 1951: Nevada State Engineer Water-Resources Bulletin, no. 12, p. 17-34.

Eakin, T. E., Schoff, S. L., and Cohen, Philip, 1963, Regional hydrology of a part of southern Nevada--A reconnaissance: U.S. Geological Survey, Report TEI-833, 40 p.

Everett, D. E., and Rush, F. E., 1964, Ground-water appraisal of Smith Creek anad Ione Valleys, Lander and Nye Counties, Nevada: Nevada Department of Conservation and Natural Resources Ground-water Resources Reconnaissance Series Report 28, $21 \mathrm{p}$.

--- 1965, water resources appraisal of Lovelock Valley, Pershing County, Nevada: Nevada Department of Conservation and Natural Resources Water-Resources Reconnaissance Series Report 32, 40 p.

Fierro, G. W., Jr., Mindling, A. L., and Illian, J. R., 1969, Section B, Regional groundwater flow systems of central Nevada: University of Nevada System, Desert Research Institute, Center for Water Resources Research Miscellaneous Report 5, 112 p. Glancy, P. A., 1968, Water-resources appraisal of Butte Valley, Elko and White Pine Counties, Nevada: Nevada Department of Conservation and Natural Resources Division of Water Resources, Water-Resources Reconnaissance Series Report 49, $50 \mathrm{p}$. 
Harrill, J. R., 1970, Water resources appraisal of the Granite Springs Valley area, Pershing, Churchill, and Lyon Counties, Nevada: Nevada Department of Conservation and Natural Resources Division of Water Resources, Water-Resources Reconnaissance Series Report $55,36 \mathrm{p}$.

--- 1968, Hydrologic response to irrigation pumping in Diamond Valley, Eureka and Elko Counties, Nevada, 1950-65, with a section on Surface water, by R. D. Lamke: Nevada Department of Conservation and Natural Resources Water Resources Bulletin no. 35, 85 p. 1971, Water resources appraisal of the Pilot Creek Valley area, Elko and White Pine Counties, Nevada: Nevada Department of Conservation and Natural Resources Division of Water Resources, Water-Resources Reconnaissance Series Report 56, 46 p. ---- 1969, Hydrologic response to irrigation pumping in Hualapai Flat, Washoe, Pershing and Humboldt Counties, Nevada, 196067, with a section on Surface water, by P. L. Soule: Nevada Department of Conservation and Natural Resources Water-Resources Bulletin, no. $37,75 \mathrm{p}$.

Harrill, J. R., and Moore, D. O., 1970, Effects of ground-water development on the water regimen of Paradise Valley, Humboldt County, Nevada, 1948-68, and hydrologic reconnaissance of the tributary areas: Nevada Department of Conservation and Natural Resources Division of Water Resources, WaterResources Bulletin no. 39, 123 p. 
Huxel, C. J., Jr., 1966, Effects of irrigation development on the water supply of Quinn River Valley area, Nevada and Oregon, with a section on Surface water, by J. E. Parkes, and Chemical quality of water, by D. E. Everett: Nevada Department of Conservation and Natural Resources water Resources Bulletin no. 34,80 p.

--- 1969, Water resources and development in Mason Valley, Lyon and Mineral Counties, Nevada, 1948-65, with a section on Surface water, by E. E. Harris: Nevada Department of Conservation and Natural Resources Division of Water Resources, Water-Resources Bulletin no. 38, 77 p.

Malmberg, G. T., 1965, Available water supply of the Las Vegas ground-water basin, Nevada: U.S. Geological Survey WaterSupply Paper 1780,116 p.

--- 1967, Hydrology of the valley-fill and carbonate-rock reservoirs, Pahrump Valley, Nevada-California: U.S. Geological Survey Water-Supply Paper 1832, 47 p. Malmberg, G. T., and Worts, G. F., Jr., 1966, Effects of pumping on the hydrology of Kings River Valley, Humboldt County, Nevada, 1957-64: Nevada Department of Conservation and Natural Resources Water-Resources Bulletin, no. 31, 59 p. Maxey, G. B., and Eakin, T. E., 1949, Ground water in white River Valley, White Pine, Nye, and Lincoln Counties, Nevada: Nevada State Engineer Water-Resources Bulletin, no. 8, 59 p. Naff, R. L., Maxey, G. B., and Kaufmann, R. F., 1974, Interbasin ground-water flow in southern Nevada: Nevada Bureau of Mines and Geology Report 20, 28 p. 
Rush, F. E., 1964, Ground-water appraisal of the Meadow Valley area, Lincoln and Clark Counties, Nevada: Nevada Department of Conservation and Natural Resources Ground-water Resources Reconnaissance Series Report 27, 43 p. ---- 1968, Water resources appraisal of the lower Moapa-Lake Mead area, Clark County, Nevada: Nevada Department of Conservation and Natural Resources Division of Water Resources, Water-Resources Reconnaissance Series Report 50, 66 p.

---- 1968, Water resources appraisal of Clayton Valley-Stonewall Flat area, Nevada and California: Nevada Department of Conservation and Natural Resources, Water-Resources Reconnaissance Series Report 45, 54 p.

---- 1968, Water resources appraisal of Thousand Springs Valley, Elko County, Nevada: Nevada Department of Conservation and Natural Resources Division of Water Resources, Water-Resources Reconnaissance Series Report 47, 61 p. -.-- 1970, Hydrologic regimen of Walker Lake, Mineral County, Nevada: U.S. Geological Survey, Hydrologic Investigations Atlas HA-415, scale $1: 62,500$. Rush, F. E., and Eakin, T. E., 1963, Ground-water appraisal of Lake Valley in Lincoln and white Pine Counties, Nevada: Nevada Department of Conservation and Natural Resources Ground-water Resources Reconnaissance Series Report 24, 29 p. 
Rush, F. E., and Schroer, C. V., 1970, water resources of Big Smokey Valley, Lander, Nye, and Esmeralda Counties, Nevada: Nevada Department of Conservation and Natural Resources Division of Water Resources, Water-Resources Bulletin no. $41,84 \mathrm{p}$.

--- 1976, Geohydrology of Smith Valley, Nevada, with special reference to the water use period, 1953-72: Nevada Department of Conservation and Natural Resources Division of Water Resources Water-Resources Bulletin, no. 43, 95 p.

Schoff, S. L., and Moore, J. E., 1968, Sodium as a clue to direction of ground-water movement, Nevada Test Site, in Geological Survey Research 1968: U.S. Geological Survey Professional Paper $600-D$, P. D30-D33.

Sinclair, W. C., 1963, Ground-water appraisal of the Pueblo Valley Continental Lake region, Humboldt County, Nevada: Nevada Department of Conservation and Natural Resources Ground-water Resources Reconnaissance Series Report, 22, $25 \mathrm{p}$.

Sinclair, W. C., 1963, Ground-water appraisal of Long Valley-Massacre Lake region, Washoe County, Nevada, with a section on The soil of Long Valley, by R. L. Malchow: Nevada Department of Conservation and Natural Resources Ground-water Resources Reconnaissance Series Report 15, 26 p.

--- 1963, Ground-water appraisal of Duck Lake Valley, Washoe County, Nevada, with a section on The soils of Duck Lake Valley, by R. L. Malchow: Nevada Department of Conservation and Natural Resources Ground-water Resources Reconnaissance Series Report 17, 19 p. 
Trexler, D. T., Koenig, B. A., and Flynn, Thomas, 1979, Geothermal resources of Nevada and their potential for direct utilization: Nevada Bureau of Mines and Geology Map, scale 1:500,000. Van Denburgh, A. S., Lamke, R. D., and Hughes, J. L., 1973, A brief water-resources appraisal of the Truckee River basin, western Nevada: Nevada Department of Conservation and Natural Resources Division of Water Resources, Water Resources Reconnaissance Series Report 57, 122 p. White, A. F., 1979, Geochemistry of ground water associated with tuffaceous rocks, Oasis Valley, Nevada: U.S. Geological Survey Professional Paper 712-E, 25 p. Winograd, I. J., and Pearson, F. J., Jr., 1979, Major carbon 14 anomaly in a regional carbonate aquifer--Possible evidence for megascale channeling, south central Great Basin: WaterResources Research, v. 1, no. 6, p. 1125-1143. Winograd, I. J., and Thordarson, William, 1975, Hydrogeologic and hydrochemical framework, south-central Great Basin, Nevada-California, with special reference to the Nevada Test Site: U.S. Geological Survey Professional Paper 712-C, 126 p.

Zones, C. P., 1961, Ground-water reconnaissance of Winnemucca Lake Valley, Pershing and Washoe Counties, Nevada: U.S. Geological Survey Water-Supply Paper 1539-C, 18 p. 